\title{
Plant-Parasitic Nematodes Associated with Garlic in Yemen
}

\author{
Mohamed, R. M. Saeed \\ Department of Plant Protection, Faculty of Agriculture, Sana'a University, Yemen. \\ E-mail: raweh2001@yahoo.com
}

\begin{abstract}
A survey was undertaken to determine the frequency and abundance of plant-parasitic nematodes associated with garlic (Allium sativum L.) in major garlic production governorates in Yemen. Twenty nematode genera were found in association with garlic in Sana'a, Ibb and Hadramout governorates of which Antarctenchus, Aphelenchoides, Aphelenchus, Basiria, Boleodorus, Ditylenchus, Helicotylenchus, Heterodera, Hoplolaimus, Meloidogyne, Microposthonia, Nothanguina, Pratylenchus, Rotylenchulus, Rotylenchus, Scutellonema, Tetylenchus, Tylenchorhynchus, Tylenchus and Zygotylenchus. All nematode genera except Aphelenchus, Helicotylenchus, Meloidogyne and Tylenchorhynchus have been reported for the first time on garlic in Yemen. The most prevalent plant nematode genera associated with garlic cultivars in all surveyed districts were Aphelenchus, Ditylenchus, Pratylenchus, Tylenchorhynchus and Tylenchus. The largest number of nematode genera was recorded in Sana'a governorate (19 genera) compared to Ibb (14 genera) and Hadramout (12 genera). Antarctenchus, Hoplolaimus, Microposthonia, Nothanguina, Scutellonema and Zygotylenchus genera were only found in Sana'a governorate, while Heterodera was recorded only in Ibb governorate. The most serious pests on garlic, stem and bulb nematode (Ditylenchus) exhibited the highest average population density of 4214 nematodes $/ 250 \mathrm{gm}$ soil with frequency of occurrence $49 \%$. Therefore, effects of nematode damage on growth, vigor and yield of garlic need further investigation.
\end{abstract}

Key words: Survey, Associated nematode genera, Garlic, Yemen.

\section{Introduction}

Garlic (Allium sativum L.) is one the most important vegetable crops in Yemen. Sana'a, Ibb and Hadramout governorates are the main garlic growing areas. The total cultivated area attained over 933 hectares with a yield production of about 4332 meter tons in 2012, and more than $79 \%$ of garlic production was produced in Sana'a, Ibb and Hadramout governorates (43\%, 18.5\% and $17.5 \%$, respectively; Agricultural Statistics, 2013). A considered number of plant-parasitic nematode genera in association with garlic cultivation have been isolated from various garlic producing areas all over the world (Sundaram et al., 1990; Silva, and Carneiro, 1992; Doucet, 1999; Aballay and Eriksson, 2006; Patel, 2007, Yu et al., 2012 and Qiao et al., 2013). Relatively, few reports have been published about plant parasitic nematodes in Yemen. Most of which only revealed the status 
of root-knot nematodes, Meloidogyne spp. on some economic crops including garlic in Yemen (Oteifa, 1975, Sikora, 1982 \&1986 and Ibrahim, 1987). El-Zoumair (1998) recorded in his list of plant diseases in the Republic of Yemen the presence of some plant parasitic nematode genera associated with some economic crops. Moreover, only the report of plant parasitic nematodes distribution on some plant crops in Yemen (Sana'a area) was published by El-Sherif, (2002) who recovered members of Aphelenchoides, Ditylenchus, Helicotylenchus, Meloidogyne, Paratylenchus, Trichodorus, Tylenchorhynchus and Xiphinema from garlic soil.

The stem and bulb nematode (Ditylenchus dipsaci) has been reported as a serious pest on garlic in many regions of the world especially in the colder and temperate regions causing necrosis or rotting of bulbs, swelling and distortion of aerial plant parts, leaf stunting, thickening, looping and yellowing and death of young plants (Netscher and Sikora, 1990; Potter and Olthof, 1993; Johnson Roberts, 1995 and Tenente, 1996).

In Yemen the stem and bulb nematode causes extensive deterioration to garlic production and can cause complete failure of the host plants (Awadh et al., 2008). Moreover, the European and Mediterranean Plant Protection Organization (EPPO) has placed D. dipsaci as No. 174 on the A2 list of phytosanitary categorization, which is distributed locally in EPPO countries, and it is regulated as a quarantine pest (EPPO, 1997).

Information of plant parasitic nematodes associated with garlic and the damage or severity caused in field plants is a meager problem in Yemen. Therefore, the present study was conducted to identify nematode genera and determine their current distribution and population density, especially in the major garlic production areas (Sana'a, Ibb and Hadramout governorates).

\section{Materials and Methods}

An extensive survey was carried out in the major garlic production areas in Yemen. A total of 134, 56, and 62 samples were collected from Sana'a (Al Haymah, Bani Matar, Bilad Al Rus and Hamdan districts), Ibb (Al Nadirah, Al Saddah and Ba'dan districts) and Hadramout (Al Qatn, Sayun and Tarim districts) governorates, respectively. Soil samples were taken from roots rhizosphere of growing plants to a depth of $10-15 \mathrm{~cm}$ with a garden spade at random locations in the field. Soil samples from each field were placed in polyethylene bags and protected from sun. The collected samples were properly labeled and taken to Plant Protection Laboratory of the Faculty of Agriculture, Sana'a University for analysis and identification of the recovered plant parasitic nematodes. Soil from each sample was thoroughly mixed and nematodes were extracted from a $250 \mathrm{gm}$ soil sample with a combination of sieving and Baerman-pan technique (Goodey, 1957). The extracted nematodes were counted using a Hawkesly counting slide and identified to generic level based on morphological characters of the adults and juveniles forms according to Mai and 
Lyon, (1975) and Siddiqi, (2000). Population density (PD) and frequency of occurrence (FO) of the extracted nematode genera were calculated and documented.

\section{Results and Discussion}

Approximately $95 \%$ of the collected samples were positive for nematode prevailing. Average abundance of nematodes ranged from 47-4214 individuals/ $250 \mathrm{gm}$ soil (Table, 1). Data reveal presence of twenty nematode genera associated with the rhizosphere of garlic plants in Sana'a (Al Haymah, Bani Matar, Bilad Ar Rus and Hamdan districts), Ibb (Al Nadirah, Al Saddah and Ba'dan districts) and Hadramout (Al Qatn, Sayun and Tarim districts ) governorates. The genera are Antarctenchus, Aphelenchoides, Aphelenchus, Basiria, Boleodorus, Ditylenchus, Helicotylenchus, Heterodera, Hoplolaimus, Meloidogyne, Microposthonia, Nothanguina, Pratylenchus, Rotylenchulus, Rotylenchus Scutellonema, Tetylenchus, Tylenchorhynchus, Tylenchus, and Zygotylenchus. The largest number of nematode genera was recorded in Sana'a governorate (19) compared to Ibb (14) and Hadramout (12). Evidently genera, of Aphelenchus, Ditylenchus, Pratylenchus, Tetylenchus and Tylenchorhynchus were recovered from samples of all surveyed districts. Members of the stem and bulb nematode (Ditylenchus) were observed in all the surveyed districts with average frequency occurrence ranging between $14-49 \%$ and population densities $62-4214$ nematodes $/ 250 \mathrm{gm}$ soil.

Antarctenchus, Hoplolaimus and Microposthonia were only found in Sana'a governorate, Bani Matar district with low FO and population densities of 235, 72 and 305 nematodes $/ 250 \mathrm{gm}$ soil, respectively, while Nothanguina was only found in Hamdan with low occurrence $4 \%$ and population density of 78 nematodes $/ 250 \mathrm{gm}$ soil. Scutellonema and Zygotylenchus were detected only in Sana'a governorate except Bilad AI Rus district. On the other hand, Heterodera was only recorded in AI Nadirah district Ibb governorate with 24\% FO and population density of 154 nematodes/250 gm soil, while Rotylenchus was found in Bani Matar and Al Nadirah districts with low FO and population densities.

In Sana'a governorate, it was evident that Bani Matar district sustained the largest number of nematode genera (18) compared to Hamdan (14), Al Haymah (10) and Bilad Al Rus (9). Seven genera, Aphelenchus, Basiria, Ditylenchus, Helicotylenchus, Pratylenchus, Tylenchorhynchus and Tylenchus were found in all surveyed districts in Sana'a governorate. The Highest density of Helicotylenchus was found in samples of Al Haymah district with 1377 nematodes/250 gm soil. In Hamdan district, Ditylenchus exhibited the highest percent of occurrence (67\%) and the highest population density of 8745 nematodes $/ 250 \mathrm{gm}$ soil.

In Ibb governorate, Al Nadirah, Al Saddah and Ba'dan districts, fourteen genera were identified from soil samples in all surveyed districts except, Heterodera, Rotylenchus and Tetylenchus which were only found in Al Nadirah 
Table (1): Density and frequenoy of occurrence of nematode genera in majo garlic production gover norates in Yemen.

\begin{tabular}{|c|c|c|c|c|c|c|c|c|c|c|c|c|c|c|c|c|c|c|c|c|c|c|c|c|c|c|}
\hline \multirow{3}{*}{ Geners } & \multicolumn{10}{|c|}{ Sana"a } & \multicolumn{8}{|c|}{ lbb } & \multicolumn{8}{|c|}{ Hadram out } \\
\hline & \multicolumn{2}{|c|}{ Al Hoymah } & \multicolumn{2}{|c|}{$\begin{array}{c}\text { Banl } \\
\text { Motar }\end{array}$} & \multicolumn{2}{|c|}{$\begin{array}{c}\text { Eled } \\
\text { Al Rus }\end{array}$} & \multicolumn{2}{|c|}{ Hamden } & \multicolumn{2}{|c|}{ Aversos } & \multicolumn{4}{|c|}{ Al N $x$ ingh Al Beddah } & \multicolumn{2}{|c|}{ Badsen } & \multicolumn{2}{|c|}{ Aversope } & \multicolumn{2}{|c|}{ All Qostn } & \multicolumn{2}{|c|}{ seyun } & \multicolumn{2}{|c|}{ Tarim } & \multicolumn{2}{|c|}{ Aversos } \\
\hline & P.D & F.O \% & P.D & F.0\% & PDO & F.O\% & $P D$ & F.OB & A.D & F.0.84 & $P . D$ & F.03\% & \& PD & FO\% & P.DF & $5.0 \%$ & \&.DF & F.0.8/ & $P D F$ & FOM & P.DF. & 5.03 & P.DF & F.09: & $P D$ & F.O.\% \\
\hline Anteratenchus & 0 & 0 & 235 & 5 & 0 & 0 & 0 & 0 & 235 & 2 & 0 & 0 & 0 & 0 & 0 & 0 & 0 & 0 & 0 & 0 & 0 & 0 & 0 & 0 & 0 & 0 \\
\hline Apehlenchololes & 0 & 0 & 75 & 5 & 210 & 7 & 216 & 4 & 145 & 4 & 106 & 43 & 32003 & 330 & 63 & 20 & 640 & 30 & 10 & 17 & 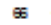 & 6 & 0 & 0 & 47 & 5 \\
\hline "Aphelen chus & 102 & 71 & 211 & 45 & 203 & 73 & 374 & 61 & 264 & 55 & 611 & 81 & 211 & $\pi$ & 270 & 80 & 398 & 79 & 85 & 17 & 41 & 14 & 390 & 38 & $2 \pi$ & 23 \\
\hline Basirte & 241 & 43 & 137 & 20 & $a s$ & 13 & 64 & 4 & 141 & 15 & 90 & 5 & 525 & 10 & 153 & 48 & 174 & 25 & 0 & 0 & 74 & 6 & 94 & 10 & 84 & 6 \\
\hline "Boleodons & 0 & 0 & 160 & 20 & 280 & 7 & 114 & 17 & 148 & 16 & 0 & 0 & 280 & 50 & 140 & 4 & 25 & 11 & 0 & 0 & $\pi$ & 17 & 0 & 0 & 77 & 10 \\
\hline Drovenchus & 121 & 43 & 144 & 41 & 557 & 33 & 845 & 67 & 4214 & 49 & 102 & 5 & 243 & 50 & 70 & 8 & 12 & 14 & 57 & 50 & 6 & 17 & 54 & 10 & 62 & 18 \\
\hline Helldh obyenehus & 1377 & 57 & 216 & 29 & 105 & 7 & 354 & 11 & 396 & 22 & 244 & 48 & 22 & 10 & 182 & 60 & 200 & 46 & 0 & 0 & $\pi$ & 6 & 0 & 0 & 70 & 3 \\
\hline "Heterodare & 0 & 0 & 0 & 0 & 0 & 0 & 0 & 0 & 0 & 0 & 154 & 24 & 0 & 0 & 0 & 0 & 154 & 9 & 0 & 0 & 0 & 0 & 0 & 0 & 0 & 0 \\
\hline "Hop Jolalmus & 0 & 0 & 7 & 2 & 0 & 0 & 0 & 0 & 72 & 1 & 0 & 0 & 0 & 0 & 0 & 0 & 0 & 0 & 0 & 0 & 0 & 0 & 0 & 0 & 0 & 0 \\
\hline Meloldogyne & 0 & 0 & 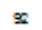 & 8 & 0 & 0 & 139 & 2 & 100 & 4 & 209 & 24 & 0 & 0 & 67 & 8 & 168 & 13 & 70 & 17 & 0 & 0 & 0 & 0 & 70 & 2 \\
\hline "Mlarop os th anle & 0 & 0 & 305 & 2 & 0 & 0 & 0 & 0 & 305 & 1 & 0 & 0 & 0 & 0 & 0 & 0 & 0 & 0 & 0 & 0 & 0 & 0 & 0 & 0 & 0 & 0 \\
\hline -Nothangutna & 0 & 0 & 0 & 0 & 0 & 0 & 78 & 4 & 78 & 1 & 0 & 0 & 0 & 0 & 0 & 0 & 0 & 0 & 0 & 0 & 0 & 0 & 0 & 0 & 0 & 0 \\
\hline "Pretyenchus & 112 & 14 & 273 & 74 & 173 & 33 & 121 & 43 & 224 & 56 & 131 & 48 & 73 & 10 & 94 & 16 & 118 & $z$ & 140 & 17 & 179 & 25 & 378 & 14 & $2 n$ & 21 \\
\hline "Rotylen chus & 0 & 0 & E & 2 & 0 & 0 & 0 & 0 & 147 & 1 & 92 & 5 & 0 & 0 & 0 & 0 & 92 & 2 & 0 & 0 & 0 & 0 & 0 & 0 & 0 & 0 \\
\hline "Rotyen chulus & 0 & 0 & 112 & 24 & 0 & 0 & 540 & 63 & 308 & 34 & 148 & 19 & 35 & 10 & 90 & 8 & 115 & 13 & 0 & 0 & 0 & 0 & 158 & 43 & 158 & 15 \\
\hline Scutellaneme & 279 & 86 & 250 & 42 & 0 & 0 & 94 & 22 & 218 & 33 & 0 & 0 & 0 & 0 & 0 & 0 & 0 & 0 & 0 & 0 & 0 & 0 & 0 & 0 & 0 & 0 \\
\hline Tetyenchus & 70 & 14 & 280 & 14 & 0 & 0 & 0 & 0 & 259 & 7 & 102 & 5 & 0 & 0 & 0 & 0 & 10 & 2 & 0 & 0 & 252 & 14 & 0 & 0 & 258 & 8 \\
\hline Tylenchorhyn ch us & 224 & 14 & 279 & 48 & 180 & 27 & 251 & 61 & 260 & 49 & 183 & 19 & 554 & so & 126 & 36 & 312 & 39 & 70 & 17 & 253 & $\infty$ & 294 & 76 & 293 & 73 \\
\hline "Tylenchus & 224 & 14 & 214 & 70 & 194 & 67 & 197 & 37 & 208 & 55 & 300 & 81 & 368 & $\boldsymbol{\infty}$ & 188 & 80 & $2 x$ & 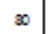 & 70 & 17 & 60 & 2 & 123 & 14 & 78 & 18 \\
\hline Zypotyenchus & 158 & 29 & 134 & 6 & 0 & 0 & $\Leftrightarrow$ & 2 & 131 & 5 & 0 & 0 & 0 & 0 & 0 & 0 & 0 & 0 & 0 & 0 & 0 & 0 & 0 & 0 & 0 & 0 \\
\hline
\end{tabular}


district, while Boleodorus and Meloidogyne were only found in Ba'dan and Al Saddah districts or Ba'dan and Al Nadirah districts, respectively. Aphelenchus and Meloidogyne genera exhibited the highest percent of occurrence and population densities in Al Nadirah district compared to different surveyed districts with $81 \%$ and 24\% FO and population densities of 611 and 209 nematodes $/ 250 \mathrm{gm}$ soil, respectively. In Al Saddah district population densities of Aphelenchoides, Tylenchorhynchus, Basiria, Tetylenchus and Boleodorus were the highest among the other surveyed districts with 3203, 554, 525, 388 and 280 nematodes/250 gm soil, respectively, while Tylenchorhynchus and Boleodorus genera exhibited the highest percent of occurrence with $90 \%$ and $50 \%$ FO, respectively. The highest frequency occurrence of Helicotylenchus and Basiria were found in Ba'dan district among the other districts with $60 \%$ and $48 \%$, respectively.

In Hadramout governorate Al Qatn, Sayun and Tarim districts twelve genera were identified from soil samples in all districts except, Meloidogyne and Rotylenchulus which were only found in Al Qatn and Tarim districts, respectively, while Boleodorus, Helicotylenchus and Tetylenchus were only found in Sayun district. On the other hand Aphelenchoides or Basiria were found in Sayun and Al Qatn or Sayun and Tarim districts, respectively.

With reference to Hadramout governorate, it was evident that most of detected genera occurred with low frequencies and population densities. Tylenchorhynchus was widely distributed especially in Sayun and Tarim with an average of $73 \%$ FO and with highest average population density of 263 nematodes $/ 250 \mathrm{gm}$ soil. The highest population density of Pratylenchus was found in Tarim district comparing to different surveyed districts in all governorates with 378 nematodes/250 gm soil and with a limited distribution (14\%).

In this survey, nematode population densities and frequency occurrences differed from one district to another, which could be explained in terms of varying local soil and weather conditions, weed types, cropping, land history, and farming practices. The lower frequency and population density of root-knot nematode (Meloidogyne) in this survey compared to Ditylenchus could be due to low temperature at the time of sampling, or to the soil types which are loamy, or clay loam being unfavorable to this nematode and may be due to differences of garlic varieties.

Members of Criconemoides (ring), Longidorus (needle), Paratylenchus (pin), Trichodorus (stubby root) and Xiphinema (dagger) which were occurred on garlic in Sana'a governorate (EI-Sherif, 2002) were not found in the present survey. On the other hand, fifteen nematode genera; Antarctenchus, Aphelenchoides, Basiria, Boleodorus, Heterodera, Hoplolaimus, Microposthonia, Nothanguina, Pratylenchus, Rotylenchulus, Rotylenchus Scutellonema, Tetylenchus, Tylenchus, and Zygotylenchus were recorded for the first time on garlic in Yemen. 


\section{References}

Aballay, E. and Eriksson, B. (2006). Trichodorid nematodes in the central area of Chile. Nematologia Medit., 34(1):43-48.

Agricultural Statistics (2013). Ministry of Agriculture Year Book, 2012, Ministry of Agric. \& Irrigation, Republic of Yemen.

Awadh, G. M.; Saeed, M. R.; Najy, A.a nd Saleh, A. M. (2008).In-vitro nematicidal activity of some selected plants on stem nematode Ditylenchus dipsaci $\mathrm{f}$. (Tylenchida: Tylenchidae). Yemeni J. of Biological Sci. 4(1):141-150.

Doucet, M. E. (1999). Soil nematodes reported in association with garlic in Argentina. Nematologia Medit., 27(2): 215-219.

El-Sherif, A. G. (2002). Survey of plant parasitic nematode genera associated with some plant crops in Sana'a area, Yemen Arab Republic. J. Agric. Sci. Mansoura Univ., 27(1): 639-647.

El-Zoumair, M. A. and Mahdy, A. M. M. (1998). Recent host list of plant diseases recorded in the Republic of Yemen. Egypt. J. of Phytopatol., Vol. 26. No.1pp.51-76.

EPPO (1997). Data sheets on quarantine pests: Ditylenchus dipsaci. In: Smith IM, McNamara DG, Scott PR, Holderness M, editors. Quarantine Pests for Europe. Wallingford, UK: CAB International, pp. 1-4.

Goodey, J. B. (1957). Laboratory methods for work with plant and soil nematodes. Tech. Bull.2, Min. Agric. Fish.\& Food, 72pp.

Ibrahim, I. K. A. (1987). The status of root-knot nematodes in the middle east, region VII of the International Meloidogyne project. In: An advanced treatise on Meloidogyne Vol: (1): Biology and, ed: Sasser, J. N. and Carter, C. C. 1985 pp. 373-378.

Johnson, A.W. and Roberts, P. A. (1995). Diseases caused by nematodes. P. 35-40. In H.F. Schwartz and S.K. Mohan (ed.) compendium of onion and garlic diseases. Am. Phytopathol. Soci. Press,ST. Paul, MN.

Mai, W. F. and Lyon, H. H. (1975). Pictorial key to genera of plant parasitic nematodes, $4^{\text {th }}$ Ed. Cornell Univ. Press, Ithaca, $219 \mathrm{pp}$.

Netscher, C.; Sikora, A. (1990). Nematode parasites of vegetables. In: Plant parasitic nematodes in subtropical and tropical agriculture (Ed. by Luc, M.; Sikora, R.A.; Bridge, J.), pp. 237-283.

Oteifa, B.A. (1975). An assignment report on nematode problems in Peoples Democratic Republic of Yemen. 24pp. 
Patel, A. D.; Panickar, B. K.; Patel, B. A.; Patel, D. J. (2007). Community analysis of plant parasitic nematodes associated with agricultural crops in Junagadh district of Gujarat and Diu-union territory. Indian J. of Nematol., 37(1):68-71.

Potter JW, Olthof THA (1993). Nematode pests of vegetable crops. In: Evans K, Trudgill DL, Webster JM, editors. Plant Parasitic Nematodes in Temperate Agriculture. Wallingford, UK: CAB International, pp. 171-207

Qiao, Y.; Zaidi, M.; Badiss, A.; B. Hughes; Celetti, M. J. and Yu, Q. (2013). Intra-racial genetic variation of Ditylenchus dipsaci isolated from garlic in Ontario as revealed by random amplified polymorphic DNA analysis. Canadian J. of Plant Pathol., 35(3):346-353.

Siddiqi, M. R. (2000). Tylenchida, parasites of plants and Insects $2^{\text {nd }}$ Ed. The Commonwealth Agric. Bureaux, Farnham Royal, Slugh SL2 3BN, UK,645pp.

Sikora, R. A. (1982). Status of root-knot nematodes Meloidogyne spp. in the Yemen Arab Republic. International Meloidogyne project contract No. AID/ta-C-1284, 1978, pp. 50-57.

Sikora, R. A. (1986). Observations on plant parasitic nematodes in Yemen with emphasis on Meloidogyne. First National Plant Protection Symposium, Ministry of Agric. And Water Resources. Sana'a, Yemen Arab Republic, $11 \mathrm{pp}$.

Silva, J. F. V. and Carneiro, R. G. (1992). Survey of Ditylenchus dipsaci in garlic areas in the Parana State. Nematologia Brasileira, 16(1/2):1-5.

Sundaram, R.; Rajendran, G.; Lakshmanan, P. L. and Nanjan, K. (1990). Nematodes associated with garlic and vegetables in Nilgris district. J. South Indian Horticulture, 38(6):353.

Tenente R.C.V. (1996). Nematode problems of bulbs, with special reference to Ditylenchus dipsaci. Nematropica, 26: 91-99.

Yu, Q.; Zaida, M. A.; Hughes, B. and Celetti, M. (2012). Discovery of potato rot nematode, Ditylenchus destructor, infesting garlic in Ontario, Canada. Plant Disease, 96(2):297-300. 


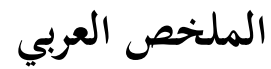

النيماتودا نباتية التطفل المصاحبة لنبات الثوم في اليمن

$$
\text { قسم وقاية النبات - كحمد راوح محمد سعيد الزراعة - جامعة صنعاء }
$$

تم إجراء حصر لتحديد نسبة التواجد والكثافة العددية للنيماتودا نباتية التطفل المصاحبة

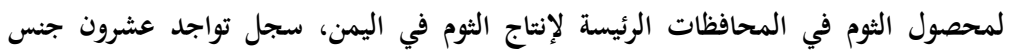

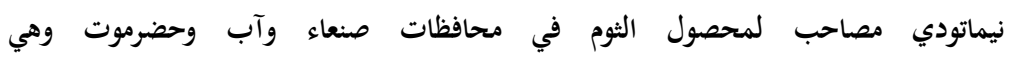
Antarctenchus, Aphelenchoides, Aphelenchus, Basiria, Boleodorus, Ditylenchus, Helicotylenchus, Heterodera, Hoplolaimus, Meloidogyne, Microposthonia, Nothanguina, Pratylenchus, Rotylenchulus, Rotylenchus Scutellonema, Tetylenchus, Tylenchorhynchus, Tylenchus, Gygotylenchus، كل الأجناس سجلت لأول مرة على الثوم في اليمن عدا الأجناس Aphelenchus, Helicotylenchus, Meloidogyne Ditylenchus, Aphelenchus, كانت الأجناس.Tylenchorhynchus و Tylenchus Pratylenchus, Tylenchorhynchus

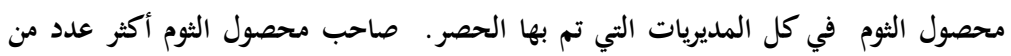

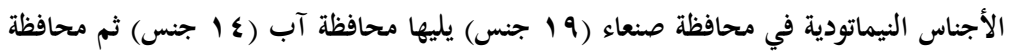

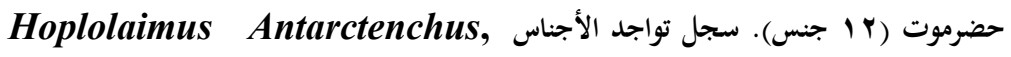
Zygotylenchus, Scutellonema ،Microposthonia, Nothanguina, في محافظة صنعاء فقط بينما سجل جنس Heterodera في محافظة آب. أظهر جنس نيماتودا السوق والأبصال Ditylenchus الذي يعد أخطر جنس نيماتودي على الثوم أعلى

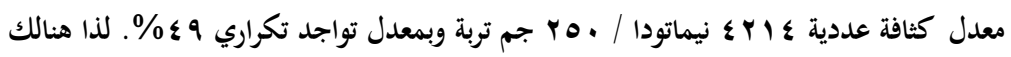

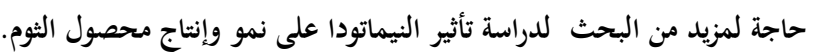

